\title{
GANDHARWA WEDA: MEMAHAMI PRINSIP KERJA KREATIF MPU KANWA ${ }^{1}$
}

\author{
Oleh: \\ I Wayan Suka Yasa \\ Pascasarjana Universitas Hindu Indonesia \\ Denpasar \\ iwayan_sukayasa@yahoo.com
}

\begin{abstract}
The object of this writing is one stanza of the Kakawin Arjuna Wiwaha. The text is reviewed to discover the worldview and creative working principle of the poet, Mpu Kanwa. In this context the analysis is based on rasa (Indian and Old-Javanese aesthetics) and semiotic theory. It is understood that purwa karma, i.e. yoga is the work of nobleness. This is the view of the world of Mpu Kanwa. The creative work is based on empowerment in an integrated and the focus between power of taste, power of mind, and power of desire. The three creative forces that gave birth to sense of art (taksu) which in the process of sustainable by itself has made someone as the center of dignity for the community.
\end{abstract}

Keywords: Gandharwa Weda, creative working principle of the poet, Mpu Kanwa

\begin{abstract}
Abstrak
Objek materi tulisan ini adalah satu bait Kakawin Arjuna Wiwaha. Teks itu dikaji untuk menemukan pandangan dunia dan prinsip kerja kreatif Mpu Kanwa. Dalam rangka itu analisis didasarkan pada teori rasa dan semiotik. Dipahamilah bahwa purwa karma, yaitu yoga adalah kerja keluhuran. Itulah pandangan dunia Mpu Kanwa. Kerja kreatifnya didasarkan pada pemberdayaan secara terpadu dan fokus antara daya rasa, daya budi, dan daya karsa. Tiga daya kerja kreatif itulah yang melahirkan taksu seni yang dalam proses berkelanjutan dengan sendirinya menjadikan seseorang sebagai pusat wibawa bagi masyarakat di lingkungannya.
\end{abstract}

Kata kunci: Gandharwa Weda, prinsip kerja kreatif, Mpu Kanwa

\section{PENDAHULUAN}

Gandharwa weda berarti pengetahuan atau ilmu seni (Moenir, 1999:346). Dalam mitos Hindu, gandharwa itu merupakan kelompok makhluk setengah dewa yang memiliki profesi sebagai seniman, yaitu seniman sorgawi, karena dapat memukau mengajar dan memotivasi penikmatnya. Dalam epos Ramayana, Mahabharata dan karya seni Hindu lainnya

1 Pokok-pokok pikiran tulisan ini pernah dipresentasikan dalam Seminar Gandarwa Weda yang diselenggarakan oleh Fakultas Pendidikan dan Seni Universitas Hindu Indonesia, 25 Agustus 2012. di Hotel Niki Denpasar. mereka dikenal sebagai para pemain musik atau penyanyi berbakat unggul (Zoetmulder, 1995:271).

Gandharwa weda yang arkhais ini mencakup bidang seni Hindu yang luas. Akan tetapi, karena keterbatasan dan bidang ilmu seni yang penulis tekuni, maka pada tulisan ini diajukan bagian kecilnya saja, yaitu sedikit tentang seni sastra Hindu Jawa Kuno (khususnya kakawin). Mengapa? Karena tema dan narasi (sebagian atau keseluruhan) karya sastra Jawa Kuno, sampai sejauh ini masih tetap diapresiasi dan banyak memberi inspirasi untuk mengembangkan karya seni tradisional Hindu 
di Indonesia (khusunya di Jawa dan Bali) lainnya. Tidak hanya itu, karya-karya monumental mpu Jawa Kuna itu bahkan dijadikan rujukan utama olah batin. Adapun topik kecil yang diajukan kali ini adalah "memahami prinsip kerja kreatif yang disebut purwa karma oleh Mpu Kanwa”.

\section{MATERI, TEORI, DAN METODE}

Materi tulisan ini adalah terpusat pada satu teks puisi Kakawi Arjuna Wiwaha. Teks-teks lainnya dijadikan pendukung penjelasan. Dalam Kakawin Arjuna Wiwāha (XII:6) Mpu Kanwa menyimpulkan prinsip hidup dan dasar kerja kreatifnya sebagai berikut.

Kadi hana purwakarma dinalih sang akarya hayu

Ulah apagĕh magĕgwana rasāgama buddhi tĕpĕt

Ya juga sudhira munggwing manah nira sang nipuna,

Karaṇa nika sukhābhyudaya niṣkala yan katěmu

Syair ini adalah satu roh yang menjadikan Kakawin Arjuna Wiwāha "hidup abadi; menjadi karya monumental", karena ditanggapi pembaca, bahkan sampai sejauh ini. Tanggapan yang muncul beragam. Benar bahwa puisi adalah dhawani 'semacam gema': satu kata diucapkan, lalu bergemalah berbagai arti lain (Hartoko, 1983:71). Untuk bait kakawin tersebut dapat diterjemahkan sebagai berikut:

"Contohnya, ada ajaran purwa karma, itu dipahami oleh orang arif.

(Purwa karma adalah) perilaku yang berpegang teguh pada (1) rasa, (2) agama, dan (3) buddhi yang tepat.

(Tiga prinsip) itu saja yang teguh ada di pikiran orang yang arif.

Bila itu ketemu, maka berhasillah diperoleh suka duniawi-rohani itu"

Tiga istilah penting dalam teks tersebut dipahami sebagai tanda bermakna yang memiliki korelasi sistemik holistik yang mengisyaratkan pandangan dunia dan cara kerja kreatif Mpu Kanwa. Untuk menemukan makna mendalam tiga istilah tersebut, maka tanda itu dibahas berdasarkan teori rasa dan semiotik. Rasa adalah sublimasi emosi dari tataran psikologis ke tataran estetik. Sementara semiotik adalah ilmu sistem tanda. Secara oprasional dua teori itu diacu secara eklitik berdasarkan metode sahredaya 'penghayatan sehati' yang bersamaan dengan itu dilakukan analisis heuristik dan hermeneutik (Bharata dalam Yasa, 2007: Reffaterre, 1978).

\section{PEMBAHASAN}

\section{(a) Para Kawi dan Mpu Kanwa}

Dari hasil penelitian para pakar sastra Jawa Kuno (Poerbatjaraka, 1952; Zoetmulder, 1983; Berg, 1985; Agastia, 1987; Wiryamartana,1990) dapat diketahui bahwa pada zaman jayanya Hindu di Nusantara abad ke-9-15 di Jawa, (yang kemudian berkelanjutan menjadi tradisi nyastra 'olah sastra' di Bali) kepandaian membuat syair (kakawin) merupakan bagian dalam pendidikan yang menjadikan orang-orang berbudaya. Di lingkungan kraton terdapat sejumlah pujangga yang disebut para kawi 'kelompok pujangga'. Fungsinya semacam lembaga sastra dan kebudayaan. Tugas para kawi itu antara lain, adalah mempelajari teks-teks religius atau teks estetik-religius berbahasa Sanskerta. Lebih lanjut yang penting adalah membahasa-Jawakan karya-karya Sanskerta terpilih; menggubah, menyalin, dan membaca atau mengapresiasi karya sastra tertentu itu untuk berbagai kepentingan. Sekiranya seperti itu pula fungsi mabebasan di Bali.

Dari isi bait manggala 'bait-bait awal' dan epilog sejumlah kakawin tampaklah bahwa ada hubungan yang erat antara raja dan pujangga. Sang raja adalah manggala 'sumber inspirasi dan berkat' bagi sang kawi. Sang pujangga menggubah syair dengan harapan dapat menambah kemasyuran sang raja dan kemakmuran kerajaan. Oleh karena itu, Berg (1985) sampai pada kesimpulan bahwa fungsi pujangga itu adalah sebagai imam magi literer. Membaca kakawin membawa pengaruh religiusmagis, yaitu menurunkan rahmat bagi kerajaan dan masyarakatnya. Diduga pula bahwa fungsi sang pujangga tidak dapat dilepaskan dari dunia keagamaan atau kebaktian. Bagi sang kawi, kakawin adalah candi pustaka. Sarana sang pujangga untuk mencapai kelepasan. Di sisi lain, sang kawi adalah guru: surya jĩāna 'suluh batin; suluh hidup' murid-muridnya. Dengan kata lain, ia adalah pusat wibawa pencinta karyanya. 
Sebagai halnya sang kawi, pembaca atau kawi muda dengan menikmati kakawin ciptaan gurunya ingin pula mencapai kelepasan

Kepada penulis kakawin yang terkenal diberi gelar mpu, kawi raja, atau kawindra 'raja para pujangga'. Menurut kedudukannya, para kawi itu ada yang disebut kawi nagara 'pujangga keraton yang tinggal di keraton; kawi wiku pujangga yang juga menjalani kehidupan religius'; Kawi súunya 'pujangga yang menjalani hidup sebagai pertapa'; kawi taruna 'pengarang muda; kawi yang masih magang'; kawi wadu 'pujangga wanita, atau istri pujangga'.

Bagian kakawin yang memuat sedikit keterangan tentang sang kawi, adalah bagian manggala dan epilognya. Dari bagian epilog Kakawin Arjuna Wiwāha dapat diketahui sedikit tentang Mpu Kanwa:

Sampun kekĕtan ing katārjuna wiwāha ta pangaranika,

Sākșāt tambay ira Mpu Kanwa tumatāmĕtu-mĕtu kakawin,

Bhrānyāpan těhĕr angharĕp smarakārya mangiring $i$ haji

Śri Airlanggha namāstu sang panikĕlan tanah anumata.

'Telah terangkai menjadi cerita, Arjuna Wiwāha namanya.

Sungguh untuk pertama kalinya $\mathrm{Mpu}$ Kanwa mengarang kakawin.

Resah, sebab saya sedang mengiringi sang raja untuk berperang.

Terpujilah Sri Airlangga. Beliau yang saya agungkan. Karena restunyalah (saya menulis kakawin) sampai anak batu tulis ini tumpul.

Dari syair penutup itu dapat diketahui bahwa pujangga yang menggubah Kakawin Arjuna Wiwāha itu bernama Mpu Kanwa. Ia mengarang di bawah perlindungan Sri Erlangga, raja Jawa Timur, wangsa Sióðok. Menurut Zoetmulder (1985:309) karya ini ditulis antara tahun 1028 dan 1035, manakala Raja Erlangga sedang melaksanakan smarakārya 'operasi militer' dalam rangka memulihkan kedaulatan kerajaan. Jadi, Mpu Kanwa adalah kawi nagara 'pujangga keraton' yang hidup pada abad ke 11. Hidup di lingkungan keraton raja Erlangga. Tugasnya adalah boleh jadi setara dengan tugas atau bahkan adalah purahita 'pendeta kerajaan', yaitu mendampingi raja (keluarga kerajaan) untuk menghibur (mengarang, menembangkan atau mengapresiasi kakawin dan literatur kerajaan lainnya), mengajar (menyampaikan sanwacana 'ungkapan-ungkapan pijak'), dan mengimbau (memberi semangat demi kejayaan dan kesejahtraan raja, kerajaan, dan masyarakatnya).

\section{(b) Purwa Karma}

Istilah purwa karma yang diajukan oleh Mpu Kanwa merupakan istilah lain dari karma yoga. Bahwa ajaran karma ini telah diajarkan oleh orang-orang arif Hindu dari sejak purwa kala 'jaman purwa'. Premis utama ajaran ini adalah ulah apageh magĕgwana rasāgama buddhi tĕpĕt 'perilaku yang berpegang teguh tepat pada rasa, agama, dan buddhi.

Ulah apagĕh dimaksud adalah amutěr tutur pinahayu 'memutar kesadaran atau membalik kesadaran dengan cara yang baik dan untuk kebaikan' (Arjuna Wiwāha, X:1); atau lebih tepat memutar balik kesadaran, yaitu dari berkesadaran umum duniawi yang melanglang buana menjadi kembali berkesadaran spiritual untuk menemukan jati diri. Caranya adalah kembali ke dalam diri dengan melakukan tapa 'panas; usaha keras'. Tapa adalah salah satu unsur ajaran kriya yoga (Yogasūtra Patanjali, II:1). Dua unsur penting lainnya adalah swadyaya 'kemadirian' dan Iśwarapranidana 'selalu ingat dan menghubungkan diri dengan Tuhan'.

Untuk dapat lebih memahami purwa karma 'prinsip kerja' ini, maka Mpu Kanwa menarasikan laku tapa Arjuna di Gunung Indrakila. Sumber kisahnya diambil dari Kitab Wanaparwa. Penggalan cerita Kakawin Arjuna Wiwàha yang kita butuhkan untuk memahami jabaran ajaran dimaksud sebagai berikut.

Dewa Indra tertimpa bencana. Indraloka hendak dijajah oleh Niwatakawaca, raja raksasa yang sakti itu. Oleh karena itu, Indra berusaha mencari bantuan. Diketahui bahwa Arjuna sedang membangun tapa di sebuah gua di lereng Gunung Indrakila. Indra menginginkan bantuan Arjuna, tetapi ia sedikit ragu akan keteguhan dan tujuan tapa-nya.

Untuk menghapus keraguan itu, Indra pertama-tama mengutus tujuh bidadari untuk menguji keteguhan hati Arjuna dalam mengendalikan nafsu asmara. Alhasil, Arjuna tidak tergiur oleh kemolekan dan rayuan para bidadari itu. 
Mendengar laporan para bidadari bahwa mereka gagal menggoda Arjuna, Dewa Indra senang. Kini ia ingin menjajagi kecerdasan dan tujuan tapa Arjuna. Dalam wujud seorang pertapa tua Indra berkunjung ke pertapaan Arjuna. Kedatangannya diterima dengan penuh hormat. Dengan tujuan menguji, Indra memuji dan sekaligus mencela laku tapa Arjuna, katanya: "Yoga yang Ananda lakukan itu sungguh menakjubkan. Tetapi aku heran, mengapa tapamu kau campur dengan perbuatan kasar? Di sampingmu ada baju perang, busur, dan pedang. Itu membuktikan bahwa engkau masih mengharapkan kesenangan dan kewibawaan. Aduh sayang tapamu itu, jika engkau tidak berkeputusan mencapai kelepasan".

Arjuna menjawab: "Benar kata Sang Pertapa. Tetapi saya terikat bakti dan kasih pada kakak, Sang Dharmaputra namanya. Untuk Beliaulah saya bertapa dengan cita-cita jaya dan berkuasa di dunia. Hendak berbuat jasa, yaitu memelihara dunia dan membahagiakan masyarakat. Itulah tujuan tapa yang saya lalukan ini".

Mendengar jawaban itu, Indra pun puas. Ia kembali ke wujud aslinya dan memberi restu. Atas restu itu bertambah mantaplah tapa Arjuna.

Niwatakawaca mengetahui bahwa Dewa Indra hendak minta bantuan Arjuna untuk mengalahkannya. Ia tahu pula bahwa kini Arjuna sedang betapa. Maka, untuk menggagalkan tapa Arjuna, Niwatakawaca mengutus patihnya, Si Muka untuk menghancurkan pertapaan.

Dalam wujud seekor babi, Si Muka mengobrak-abrik Gunung Indrakila. Arjuna merasa terganggu. Ia pun bangkit dari tapa-nya lalu memanah si pengganggu. Sementara dari sisi lain, Dewa Siwa dalam wujud Kirata 'pemburu', juga memanah babi itu. Panah Arjuna dan Kirata mengenai titik sasar yang sama dan ajaib, panah itu menyatu. Arjuna hendak mencabut panahnya, tetapi ditegur oleh $\mathrm{Si}$ Pemburu. Katanya menghardik: "Hai pertapa, mengapa kau ambil panahku. Ini binatang buruanku. Penampilanmu saja pertapa, hatimu busuk. Tak tahu malu".

Dihardik begitu, Arjuna tersinggung. Perkelahian pun terjadi dengan sengitnya. Keberanian Arjuna teruji. Maka menjelmalah Sanghyang Úiwa di hadapannya. Arjuna lalu memuja-Nya. Úiwa menganugerahinya panah caduśakti, Pasupati namanya.
Dari narasi singkat itu dapat kita ketahui bahwa tapa itu adalah wujud pelatihan karma yoga. Diketahui bahwa dasar tapa Arjuna adalah bhakti lawan asih 'bakti dan kasih'. Bhakti itu mengisyaratkan kesediaan untuk berkurban, yaitu mengurbankan kepentingan diri dengan tujuan mahaywang rāt lawan kaparahitan 'memelihara dunia dan mensejahterakan masyarakat' (Arjuna Wiwàha, VI:4-5).

Untuk mencapai keberhasilan seperti itu Mpu Kanwa mengisyaratkan bahwa orang harus memiliki kualitas berupa (1) kemampuan mengendalikan emosi, seperti Arjuna yang tidak tergoda oleh kemolekan dan rayuan para bidadari; (2) wawasan spiritual dan duniawi yang memadai, seperti tercermin dalam dialog Arjuna dengan Indra; (3) keteguhan pendirian dan keberanian untuk berjuang menghadapi segala bentuk rintangan yang menghalangi perjalanan hidup, seperti ketangguhan dan keberanian Arjuna dalam perang tanding dengan Kirata (Úiwa).

Dalam rangka mengembangkan kualitas diri itulah kita perlu amutěr tutur pinahayu' memutar balik kesadaran dengan benar dan baik', yaitu melalui olah rasa, àgama, dan buddhi. Prinsip amuter tutur Mpu Kanwa itu tampaknya sejalan dengan proses kerja kreatif yang diajukan oleh Ki Hajar Dewantara (Suryadi, 1995:117) dengan nama trisakti: pikiran, rasa, dan karsa. Menurut hematnya, trisakti itulah jiwa manusia. Dan manusia yang berdaya cipta (beradab; berkarakter) akan mengelola potensi triksaktinya ke dalam tindakan yang konkret. Untuk dapat mengelola tutur 'kesadaran', maka mari kita pahami tiga unsur tutur: rasa, àgama, dan buddhi itu sebagai berikut.

\section{(c) Rasa}

Rasa dalam konteks seni Hindu, seperti dikatakan oleh Dick Hartoko (1983:68) tidak tepat sama artinya dengan kata rasa dalam bahasa Indonesia, yaitu perasaan atau emosi. Emosi dalam bahasa Sansekerta adalah bhāwa. Menurut Bharata dalam kitab Nātyaśāstra emosi itu ada delapan: (1) rati 'cinta'; (2) hāsa 'humor'; (3) úoka 'sedih'; (4) krodha 'marah'; (5) utsāha 'teguh'; (6) bhaya 'takut'; (7) jugupsā 'muak'; dan (8) wismaya 'heran'. Kemudian Abhinawagupta menambah satu emosi lagi, yaitu úama 'tenang' (Wiryamartana, 1990:355-256). 
Rasa adalah pengalaman estetik atau emosi yang dibangkitkan secara estetik oleh lingkungan dan situasi artistik. Rasa merupakan revelasi atau pewahyuan makna esensial dari berbagai hal (peristiwa, orang, barang, dst). Dalam revelasi atau ilham atau penerangan itulah terletak keindahan. Dikatakan bahwa, dalam rasa terjadi sublimasi emosi dari tataran psikologis ke tataran estetik. Dalam proses sublimasiitu emosi individual ditransformasikan menjadi rasa 'pengalaman estetik': Individu lupa akan dirinya dan mencapai titik pandang universal yang membawa kebahagiaan tertinggi. Lewat pengalaman estetik horison seseorang diperluas. Rasa bukanlah persepsi akal budi, melainkan suatu pengalaman yang penuh kebahagiaan, sehingga pengalaman pribadi pun lenyap. Maka dikatakan bahwa pada titik itu, pengalaman estetik menjadi identik dengan pengalaman religius, yaitu bila perasaan manusia terbenam di dalam Brahman 'Tuhan' (Hartoko, 1983:71;Warder dlm Wiryamartana, 1990:356).

Rasa dialami jika orang dapat mengadakan identifikasi diri dengan barang atau peristiwa yang diamatinya. Ketika itu ia merasa takjub atau kagum. Jadi, hanya orang yang dapat merasa takjub, dapat mengalami kebahagiaan estetik. Dan kebahagian estetik itu mengandaikan tentang batin yang murni dan jernih (Hartoko, 1983:72). Maka, ketika Mpu Kanwa melihat bayangan bulan di dalam tempayan yang berisi air jernih lalu bersyair penuh kearifan:

Śaśiwimba haneng ghața mesi banyu,

Ndan asing śuci nirmala mesi wulan,

Iwa mangkana rakwa kiteng kadadin,

Ring angamběki yoga kiteng sakala

'Bayangan bulan pada tempayan berisi air.

Tetapi, hanya pada tempayan yang berisi air jernih menapakkan bulan.

Seperti itulah Engkau pada setiap ciptaan.

Pada ia yang menekuni yoga Engkau nyata hadir'.

Katěmunta mareka si tan katěmu, Kahidęepta mareka si tan kahidęp, Kawĕnangta mareka si tan kawĕnang Paramārtha śiwatwa nirawarana (Arjuna Wiwaha, XI:1)
'Maka dijumpailah Itu yang sebelumnya tidak pernah ditemui.

Dipahamilah Itu yang sebelumnya tidak pernah dipahami.

Dialamilah Itu yang sebelumnya tidak pernah dialami.

Yaitu tujuan utama, Sang Hakikat, Úiwa itu tidak terhalang lagi'.

Syair itu menunjukkan bahwa seorang mpu adalah orang yang dapat melihat; ia melihat ke dalam hakikat barang-barang dengan aneka sifatnya. "Melihat" itu semacam intuisi. Intuisi itu dilahirkan karena kontak dengan hakikat barang-barang. Batin sang mpu terbenam seluruhnya di dalam gambar puitik lalu dilahirkan ke luar dan dipersepsi oleh pembaca. Artinya, rasa itu pertama-tama terdapat di dalam batin sang mpu (Hartoko, 1983:72), lalu ketika rasa itu telah diekspresikan dalam bentuk karya seni dan jika dinikmati oleh pembaca, maka rasa itu pun muncul pada dirinya.

Jika bhāwa ada sembilan, maka rasa pun ada sembilan. Bhāwa dan juga rasa tidak selalu tampak dalam keadaan yang murni, tetapi sering tercampur, saling berhubungan, dan bersifat sementara. Jumlah modulasinya beragam:

\begin{tabular}{|l|l|l|}
\hline No & \multicolumn{1}{|c|}{ Bhàwa 'emosi' } & Rasa 'pengalaman estetik' \\
\hline 1 & Rati 'cinta' & Śrnggāra 'asmara' \\
\hline 2 & Hāsa 'humor' & Hāsya 'komik' \\
\hline 3 & Śoka 'sedih' & Karuṇa 'belas kasihan' \\
\hline 4 & Krodha 'marah' & Raudra 'ganas' \\
\hline 5 & Utsāha 'teguh' & Wīra 'kepahlawanan' \\
\hline 6 & Bhaya 'takut' & Bhayānaka 'khawatir' \\
\hline 7 & Jugupsā 'muak' & Bībhatsa 'ngeri' \\
\hline 8 & Wismaya 'heran' & Adbhuta 'takjub' \\
\hline 9 & Sama 'tenang' & Śānta 'damai' \\
\hline
\end{tabular}

\section{(d) Àgama}

Kata àgama (bahasa Sansekerta) berarti doktrin atau aturan tradisional yang semacam itu (Zoetmulder, 1995:12). Dalam Kakawin Arjuna Wiwāha ditemukan kata rasāgama. Dalam tradisi mabebasan kata itu diterjemahkan dengan arti 'intisari ajaran agama atau hakikat ajaran agama'. Akan tetapi, dalam konteks teks itu saya lebih memahaminya sebagai dua istilah yang berbeda, yaitu rasa dan àgama. Istilah àgama dimaksud lebih saya maknai sebagai tradisi suci, yaitu perilaku bajik 'baik dan 
bijaksana' seperti yang diisyaratkan oleh Mpu Kanwa dalam manggala kakawinnya (I:1):

Amběk sang paramārtha paṇdita huwus limpad sakeng śūnyatā,

Tan sangkeng wiṣaya prayojana nira lwir sanggraheng lokika,

Siddhāning yaśa wiryya donira sukāning rāt kininkin nira,

Santoșā hĕlětan kĕlir sira sakeng sang hyang jagatkāraṇa.

'Batin orang arif yang telah mencapai tujuan tertinggi telah mengatasi segalanya, karena menghayati Kesuungan.

Bukan karena terdorong oleh nafsu duniawi Beliau mencapai tujuan. (Kehadirannya) seolah-olah saja menyambut yang duniawi.

Sempurnanya jasa dan kebajikan itulah tujuan Beliau, maka kebahagiaan masyarakat itulah yang diusahakannya.

(Perbawanya) tenang sentosa, (Beliau) hanya sebatas tabir dengan Sang Pencipta Alam Semesta'.

Jadi, àgama itu tidak semata-mata berarti teks atau doktrin suci, tetapi yang tidak kalah pentingnya justru adalah sikap dan perilaku beradab; bermoral. Apalah artinya agama tanpa tindakan bermoral. Oleh karena itu, tradisi Bali mengatakan: "pamatin agamane tuah solah luih" 'tanda utama seorang beragama adalah perilaku yang berperikemanusiaan'. Dan dalam konteks Hindu, perilaku bermoral itu disebut suśila. Mpu Kanwa mendefinisikan tindakan bermoral itu dengan kalimat: Siddhāning yaśa wiryya donira sukāning rāt kininkin nira keberhasilan dalam berbuat jasa dan kebajikan, yaitu mengusahakan kebahagian masyarakat, itulah tujuan hidup orang arif'.

Keberatan saya menerima rasāgama sebagai satu istilah, karena maknanya akan berimpit dengan makna istilah yang mengikutinya yaitu buddhi těpĕt. Arti istilah buddhi těpĕt adalah mengacu kepada tattwa 'ajaran hakikat; filsafat'. Tattwa inilah inti sari ajaran agama Hindu. Jadi, sama artinya dengan arti rasāgama yang dipahami dalam tradisi mabebasan selama ini.

Àgama dalam arti suśila memiliki sepuluh unsur, dikenal dengan istilah dasasíla. Dalam kitab Saracamuscaya rinciannya: (1) ahingsa 'tidak membunuh'; (2) brahmacarya 'mengendalikan nafsu seks'; (3) satya 'jujur'; (4) awyawahārika 'tidak bersengketa'; (5) astenya 'tidak mencuri'; (6) akrodha 'tidak marah' (7) guruśusrūṣa 'bakti kepada guru'; (8) úauca 'hidup suci'; (9) àhàralàghawa 'mengendalikan nafsu makan'; dan (10) apramāda 'tidak suka mencela atau mencemooh'.

Suśila dalam konteks yoga, Maharsi Patanjali menyebutnya dengan istilah yama-niyama brata 'sepuluh janji atau perilaku bajik'. Sepuluh perilaku bajik ini adalah dasar angamběki yoga 'pelatihan yoga'. Rinciannya sedikit berbeda dengan dasaśila di atas. Yama-niyama brata sebagai berikut. (1) ahimsā 'tidak membunuh'; (2) satya 'jujur'; (3) asteya 'tidak mencuri; (4) brahmacarya 'mengendalikan nafsu seks'; (5) aparigraha 'hidup sederhana'; (6) úauca 'hidup suci'; (7) santosa 'sentosa; puas; penuh rasa syukur'; (8) tapa 'tahan uji'; (9) swādyāya 'mempelajari kitab suci'; dan (10) Iśwarapranidhāna 'memusatkan pikiran dan bakti kepada Tuhan (Sura, 2009:26-27). Dengan demikian, àgama dimaksud dalam hubungannya dengan teks yang dibahas dapat dipahami maknanya sebagai daya karsa manusia.

\section{(e) Buddhi}

Kata buddhi memiliki banyak arti. Arti leksikal yang lebih dekat hubungannya dengan pembicaraan ini, antara lain, adalah kekuatan pembentuk dan penyimpan buah pikiran, kecerdasan, akal, budi, semangat, hati, ingatan (Zoetmulder, 1995:138).

Buddhi adalah tattwa 'kategori' kedua dari 25 unsur ajaran filsafat Samkhya, yaitu unsur psikologis yang disebut intelegensi. Fungsi buddhi adalah untuk memberikan pertimbangan dan memutuskan segala apa yang datang dari alat persepsi yang lebih rendah yang disebut manas 'pikiran' dan indriya 'indera'. Dalam keadaan yang murni buddhi memancarkan sifat dharma 'kebajikan', jñāna 'kearifan', wairāgya 'ketidak-terikatan', dan İ́wwarya 'ketuhanan' (lihat pula Wrhaspati Tattwa, 24). Mpu Kanwa mengistilahkan buddhi yang murni dengan istilah buddhi těpĕt 'budi yang tepat'. Sedangkan Ida Ketoet Djelantik (1905-1961), pengarang Geguritan Sucita Subudi, menyatakannya dengan istilah subudi. Lalu budi murni itu dipersonifikasikannya dengan nama Sang 
Subudi, yakni tokoh pembimbing sahabatnya yang bernama Sang Sucita, personifikasi ahamkara satwika 'perasaan yang baik' dua tokoh utama Geguritan Sucita Subudi. Dikatakan pula bahwa buddhi yang murni itu berada amat dekat dengan puruṣa 'roh' Oleh karena itu, buddhi mencerminkan kesadaran roh (Sura, 2009:9).

Untuk memperoleh empat sifat buddhi (dharma, jñāna, wairagya, dan İúwarya) itu, Mahàrsi Patanjali menawarkan tiga cara melatih pikiran: (1) anumāna pramaṇa 'berpikir berdasarkan penalaran empirik'; (2) pratyakșa pramana 'berpikir berdasarkan penalaran logis'; dan (3) úabda pramaṇa 'berpikir berdasarkan teks wahyu'. Berpikir dengan tiga penalaran itulah yang dimaksud dengan buddhi tĕpĕt 'berpikir benar'. Sebaliknya, berpikir tanpa atas dasar bukti-bukti empirik disebut wikalpa 'menghayal'; berpikir tanpa penalaran logis disebut nidra 'alpa'; dan berpikir tanpa didasarkan pada teks wahyu disebut smrti 'suka mengingat yang bukan-bukan' (Yogasūtra,I:6-11). Oleh karena itu, Mpu Kanwa menegaskan pendiriannya sekaligus menggugah kita dengan bersyair (Arjuna Wiwāha, XII:7):

Syapa kari tan temung hayu masādhana sarwa hayu,

Niyata katěmwaning hala masādhana sarwa hala,

Těwas alisuh manangśaya purākrĕta tāpa tinu,

Sakaharĕpan kasiddha maka darśana Pandusuta.

'Siapakah ia yang tidak memperoleh kerahayuan jika telah bersaranakan segala yang rahayu?

Pastilah ia memberoleh yang tidak rahayu karena bersaranakan segala yang tidak rahayu.

Memprihatinkan sekali orang yang menyangsikan purwa karma, lalu apakah yang dijadikannya pegangan hidup?

Segala cita-cita diperoleh jika mencontoh laku hidup Arjuna'.

Dalam syair terkutif di atas Mpu Kanwa tegas dengan keyakinannya, bahwa purwa karma atau pura krĕta adalah sadhana 'sarana yang baik' untuk memperoleh sarwa hayu 'segala yang baik'. Segala yang baik itu, dalam konteks Hindu disebut catur purușārtha 'empat tujuan hidup': dharma 'jasa baik', artha 'kekayaan', kàma 'kenikmatan'; dan mokșa 'kebahagiaan'.

\section{(f) Amutêr Tutur Pinahayu}

Seperti telah disebutkan, bahwa ajaran purwa karma Mpu Kanwa ini memiliki tiga unsur utama, yaitu (1) rasa, (2) àgama, dan (3) buddhi. Ketiga unsur itulah yang mesti diberdayakan dengan tĕpĕt 'tepat', yaitu denan cara amutěr tutur pinahayu 'mengolah kesadaran dengan cara yang baik'. Olah kesadaran itu adalah ulah apagěh dan těpĕt 'usaha keras dan fokus', yaitu usaha mensinergikan rasa, āgama, buddhi sehingga menjadi daya rasa, daya budi, dan daya karsa. Rasa berurusan dengan keindahan indahjeleknya sesuatu; àgama berurusan dengan moral atau baik-buruknya tingkah-laku; buddhi berurusan dengan kebenaran atau benarsalahnya sesuatu. Kebenaran, kebaikan, dan keindahan adalah tri-tunggal yang menjadi nilai dasar kemanusiaan. Sifatnya universal dan satu sama lain tidak dapat dipisahkan. Dalam terminologi Hindu ketiga nilai hakiki itu dikukuhkan sebagai subhasita 'motto; ungkapan bijak': satyam-śiwam-sundaram. Ketiganya adalah ekspresi yang menyatakan kehadiran Tuhan. Dalam wujud daya budi Tuhan itu adalah Satyam 'Kebenaran'; dalam wujud moral Tuhan itu adalah Úiwam 'kebajikan'; dan dalam wujud rasa Tuhan itu adalah Sundaram 'Keindahan'. Dikatakan bahwa madzab Skolastik, pada abad pertengahan di Eropa, juga telah menandaskan, bahwa segala sesuatu yang ada, sejauh itu ada, bersifat tunggal, benar, baik, dan indah (Hartoko, 1983:9).

Ketiga daya itu, seperti yang diisyaratkan oleh Mpu Kanwa, akan memberi manfaat jika telah berhasil disinergikan. Katanya tandas: Yan katěmu 'jika berhasil disinergikan atau ditunggalkan', maka sakaharěpan kasiddha 'segala yang dicita-citakan pasti diperoleh'. Dalam kalimat lain, Mpu Kanwa berkata: Sakatilanganing amběk tan wyarthān dadi kapitūt (Arjuna Wiwàha, VI:2) 'segala yang dihasrati dengan pikiran terfokus tidak bisa tidak jadi diperoleh'. Maka, untuk lebih menegaskan pandangannya, sekali lagi Mpu Kanwa mengimbau: "Satiru-tirun kretārtha sira 
deni kadhāra nira" 'Tirulah laku hidup Arjuna dalam meraih cita-cita. Ia berhasil karena keteguhan usaha tapa-nya'. Mengapa?

Bukankah jawabannya telah dinarasikan oleh Mpu kanwa, bahwa tapa yang dhìra 'teguh' telah terbukti lewat berbagai tahapan ujian: kerelaan berkurban, mental, kecerdasan, keberanian, dan kebaktian. Bukankah hal itu yang menyebabkan Arjuna berhasil memperoleh anugerah yang durlabha 'sulit diperoleh orang umumnya'. Betapa bahagianya Arjuna mendapatkan penampakan Bhatara Úiwa dan panah Pasupati. Pasupati itu adalah caduśakti: (1) jñ̄ana śakti 'daya intelektual'; (2) kriya śakti 'daya kerja'; (3) wibhu śakti 'daya material'; dan (4) prabhu śakti 'daya kuasa'. Keempat daya itulah keesaan Úiwa.

Ia yang berhasil mendapat anugerah Úiwa, seperti Arjuna itu, disebut oleh Mpu Kanwa sebagai sang paramārtha paṇụta 'orang bijak yang telah mencapai tujuan utama', yaitu sang... huwus limpad sakeng śünyata 'orang yang telah mengalami pengalaman spiritual'. Dan kepada ia yang demikianlah sang mpu bersedia mengabdikan diri. Katanya: "Uṣṇisangkwi lebūni pāduka nira sang mangkana lwir nira, manggeh manggalaning mekĕt...." 'Aku persembahkan sanggul rambutku untuk membasuh debu ceripu Beliau, orang yang seperti itu perilakunya. Beliaulah yang aku tetapkan sebagai pembimbing (hidupku) sebagai seniman'.

Mpu 'pujangga, seniman' itu bukanlah orang yang dilayani, tetapi orang yang bersedia dengan tulus melayani. $M p u$ itu menjadi mulia karena ketulusannya melayani. Selain mpu ada juga kelompok orang yang mendapat kehormatan karena melayani, mereka disebut jurudyah seperti yang diterangkan oleh teks syair Kakawin Sumanasāntaka (147:160, terkutip di awal tulisan ini), bahwa jurudyah 'pemimpin abdi setia raja; abdi dharma' itu adalah orang-orang terpilih karena memiliki kemampuan profesional dan berkarakter luhur: prajñ $\bar{a}$ 'bijakasana', wìra 'pemberani', dan gandharwa 'seni, terampil'.

Untuk mendapat kedudukan sebagai dan jurudiyah itu, hal yang pertama-tama harus diusahakan adalah belajar untuk mendapatkan guna-widya. Guṇa adalah karakter mulia dan widya adalah ilmu pengetahuan. Setelah memiliki guna-widya orang baru dimungkinkan memiliki guna-karma 'kemampuan kerja profesional'. Guna-karma inilah yang menjadi faktor penentu utama warna 'status dan sumber hidup seseorang'. Dalam Kakawin Nitiśastra (V:1) dijelaskan:

Tati-takining sewaka guna-widya,

Smara-wisaya rwangpuluh ing ayusya,

Tengahing tuwuh sanwacana ya gĕgön,

Patilareng àtmeng tanu pagurokĕn

'kewajiban pertama seorang abdi dharma adalah berusaha keras untuk mendapatkan karakter mulia dan ilmu pengetahuan;

Kewajiban kedua setelah dua puluh tahun (masa belajar) adalah berusaha keras untuk mendapatkan arta dan kama; Kewajiban ketiga, setelah tengah umur (masa pensiun) seorang abdi dharma hendaknya tekun mendalami ajaran hakikat dengan mempelajari wacanawacana suci;

Dan yang keempat, abdi dharma hendaknya berguru kamoksan unuk dapat ilmu mati benar, yaitu ilmu agar dapat melepas roh dari tubuh'.

\section{PENUTUP}

Belajar untuk mendapatkan guna-widya 'karakter mulia dan ilmu pengetahuan profesional' adalah salah satu unsur dasar terpenting ajaran purwa karma. Guna-widya itu tiada lain adalah daya sakti pertama dan utama. Dengan itu, purwa karma 'yoga adalah kerja keluhuran' dapat menjadi kokoh sebagai pandangan dunia. Daya sakti utama itu, dalam aspeknya yang tiga adalah daya rasa, daya budi, dan daya karsa. Kesatuan sistemiktiga daya itulah sebab yang dapat menjadikan guna-karma itu menjelma menjadi taksu 'kharisma'. Kanwa menyimpulkan, hidup adalah kerja. Kerja profesional berketuhanan adalah yoga. Dengan memahami dan sekaligus memperaktekkan pandangan dunia dan prinsip kerja kreatif itu pembaca diyakinkan dapat menjadi pusat wibawa bagi masyarakat sekitar. Semoga. 


\section{DAFTAR PUSTAKA}

Hartoko, Dick. 1984. Manusia dan Seni. Yogyakarta: Yayasan Kanisius.

Monier, Sir Williams. 1999. Sanskrit-English Dictionary. Delhi: Motilal Manarsidass Publishers.

Palguna, IBM Dharma. 2000. Cara Mpu Monaguna Memuja Siwa. Denpasar: Yayasan Dharma Sastra.

Rangacharya, Adya. 1999. Natyasastra English Translation With Critical Notes. New Delhi: Munshiram Manoharlal Publishers Pvt Ltd.

Riffaterre, Michael. 1978. Semiotics of Poetry. London: Indiana University Press.

Sharma, Madama Mukunda. 1987. "The Theory of Rasa In Sanskrit Literature". Widya Pustaka. Denpasar: Fakultas sastra Universitas Udayana.

Sura, I Gede. 2009. Sāmkya dan Yoga. Denpasar: Lembaga Penelitian Universitas Hindu Indonesia.

Suryadi, AG. Linus. 1995. Dari Pujangga ke Penulis Jawa. Yogyakarta. Pustaka Pelajar.

Warna, I Wayan, dkk. 1990. Arjuna Wiwaha Kakawin Miwah Tegesipun. Denpasar: Dinas Pendidikan Denpasar.

Wiryamartana, I Kuntara. 1990. Arjuna Wiwāha Trnsformasi Teks Jawa Kuno Lewat Tanggapan dan Penciptaan di Lingkungan Sastra Jawa. Jogjakarta: Duta Wacana University Press.

Yasa, I Wayan Suka. 2007. Teori Rasa: Memahami Taksu, Ekspresi \& Metodenya. Denpasar: Widya Dharma.

----. 2010. Rasa: Daya Estetika Religius Geguritan Sucita. Denpasar: Sari Kahyangan.

Zoetmulder, P.J. 1983. Kalangwan Sastra Jawa Kuna Selayang Pandang. Jakarta: Djambatan.

Zoetmulder, P.J. dan S.O Robson. 1995. Kamus Jawa Kuna-Indonesia 1\&2. Jakarta: Gramedia Pustaka Utama. 